\title{
lan Prior and epidemiology in New Zealand
}

\section{N Pearce}

Correspondence to:

Dr N Pearce, Centre for Public Health Research, Massey

University Wellington Campus, Private Box 756, Wellington,

New Zealand;

n.e.pearce@massey.ac.nz

Accepted 15 April 2009

\section{ABSTRACT}

Ian Prior was born in Masterton, New Zealand, in 1923, and died in Wellington, New Zealand, in 2009. In 1959 lan became the Director of the Medical Unit at Wellington Hospital, and in the early 1960s he established the Epidemiology Unit. Without doubt he is the founder of epidemiology in New Zealand, and has also had a major influence in Australia and further afield. I was delighted to be invited to write this piece about lan for the Journal of Epidemiology and Community Health, not as an obituary but as an essay on an epidemiologist who inspired many of us in New Zealand, and whose example will continue to inspire many around the world. lan Prior's work represents not only an important historical legacy but also an important guide to the future of epidemiology. This includes his work on the effects of social and environmental changes and the wider social context on individual "lifestyle", his willingness to work collaboratively with researchers from other disciplines including social scientists, his insistence on seeing quantitative biomedical phenomena (such as blood pressure) in the wider social context, and perhaps most of all his insistence that epidemiologists cannot hide from the wider realities of the world in which they live.

Those who attended the funeral of Ian Prior in Wellington, New Zealand, on 23 March 2009 participated in an event that could only have occurred in New Zealand, and could only have occurred because of Ian. Speakers and performers included leaders in epidemiology, medicine, music, the visual arts, activists for social justice, Māori and Pacific community leaders, gang leaders and many others. The amazing range of people who Ian had inspired and brought together was reflected in the closing of the ceremony. Ian had done a great deal of work in prisons, and with gangs, in the last years of his life, and his coffin was escorted from the church by Black Power gang members performing a haka. The sounds of the haka were then replaced by the gentle sounds of "Mac the Knife", one of Ian's favourite songs, which he had requested be played at his funeral. I was delighted to be invited to write this piece about Ian for the Journal of Epidemiology and Community Health, not as an obituary but as an essay on an epidemiologist who inspired many of us in New Zealand, and whose example will continue to inspire many around the world.

Ian Prior was born in Masterton, New Zealand, in 1923. ${ }^{2} \mathrm{He}$ graduated from Otago Medical School in 1945, and undertook postgraduate training in London, Boston and Leeds before returning to New Zealand to work at Wellington Hospital in January 1946. ${ }^{1}$ In 1959 Ian became the Director of the Medical Unit at Wellington Hospital, and in the early 1960s he established the Epidemiology Unit. Without doubt, he is the founder of epidemiology in New Zealand, and has also had a major influence in Australia and further afield. His contribution is celebrated in the Ian Prior Oration, which is presented at the Annual Meeting of the Australasian Epidemiology Association.

Ian's early work focused on Māori health, but he also turned his attention to the Pacific, and in 1964 he conducted the first epidemiological research in Rarotonga. In 1967, he established the Tokelau Island Migrant Study, ${ }^{3}$ which became his most famous work. ${ }^{4}$

I am not going to review Ian's epidemiological work in detail. If education is what is left once everything that we learnt at school is forgotten, research is what is left when individual studies and publications are forgotten, or languish uncited in the Medline deep archive. Many of Ian's studies are classics and will be cited for many years to come. However, I want to discuss two more general, and more profound, lessons from Ian's work.

First, Ian showed that the "lifestyle-related" diseases such as diabetes and heart disease were caused by social and environmental changes such as migration, which produced changes in individual-level risk factors such as diet. This work is as relevant today as it was back in the 1960s. In particular, it is this recognition of the population context that is the key feature of the developing "global epidemiology" in the 21st century. ${ }^{5}{ }^{6}$ Even if one is focusing on specific risk factors, it is crucial to recognise that every population has its own history, culture, and economic and social divisions that influence how and why people are exposed to specific risk factors. ${ }^{7}$ The Tokelau Study is one of the most prominent examples of this during the "modern epidemiology" era, in that individual lifestyle factors such as diet, and individual health measures such as blood pressure, were studied in the social context of immigration using a multidisciplinary approach. ${ }^{4}$ Ian had an amazing ability to break through the "silos" between research disciplines, and to bring together a wide variety of researchers to address a common problem. He was able to do this because he took a "problem-based" approach, and adopted appropriate multidisciplinary methodology to address the problem (eg, the health effects of immigration) rather than letting the methodology determine the questions that were to be asked. ${ }^{56}$

These issues are likely to become more important because not only is epidemiology changing, but the world that epidemiologists study is also rapidly changing. We are "migrating" to a new world that is likely to appear just as alien and strange to us as New Zealand must have appeared to Tokelau Islanders when they migrated from their remote atolls in the 1960s. The last few 
decades have seen the occurrence of the "information revolution", which is having effects as great as the previous agricultural and industrial revolutions. These are being accompanied by the effects of economic globalisation, structural adjustment, climate change and economic recession (or depression). All of these factors have the potential to swamp the relatively minor effects of the changes in individual lifestyle that have been the focus of "risk factor" epidemiology. Thus, epidemiology is inevitably entangled with society and it is not feasible or desirable to study the causes of disease in the abstract. ${ }^{8}$ To understand the causation of disease in a population, it is essential to understand the historical and social context, and to emphasise the importance of diversity and local knowledge rather than only searching for universal relationships. This requires a quite different approach to epidemiological methods and epidemiological practice from the one that has been followed in recent decades. ${ }^{5}$ "If we are to go "back to the future" and rediscover the population perspective in epidemiology, then Ian Prior's work provides an important reference point.

Second, Ian showed that physicians should be concerned about all of the determinants of health, including macro-level factors. As well as his epidemiological research, Ian campaigned tirelessly for a wide range of social and political causes. He was one of the first environmentalists in New Zealand, and headed the successful campaign in the 1960s and 1970s to stop the raising of Lake Manapouri, one of New Zealand's most beautiful lakes, for a hydroelectric scheme for an aluminium smelter. In 1976 he was prominent in the movement to protest against "dawn raids" against "overstayers" from the Pacific. He was involved in the movement to oppose apartheid, including the protests against the South African rugby tour in 1981, which saw some of the largest and most lengthy civil disturbances in New Zealand's history, and which resulted in a virtually complete international sporting boycott of South Africa, hastening the end of the apartheid regime. In 1982 he established the New Zealand Branch of International Physicians for the Prevention of Nuclear War. It rapidly became the most successful National Branch in the world, with about one-half of all New Zealand medical doctors being members. As noted above, in his later years he worked in prisons, and with gang members, many of who became frequent visitors to his house in the upper class Wellington suburb of Wadestown. While doing all of this, and his day job as an epidemiologist, he and his wife Elespie were major sponsors of the arts in New Zealand, nurturing the careers of many singers, musicians and painters, and establishing the Wellington Sculpture Trust, which has raised funds for more than 20 sculptures now located throughout the city.

Ian Prior's work represents not only an important historical legacy, but also an important guide to the future of epidemiology. This includes his work on the role of social and environmental changes and the wider social context on individual "lifestyle", his willingness to work collaboratively with researchers from other disciplines including social scientists, his insistence on seeing quantitative biomedical phenomena (such as blood pressure) in the wider social context, and perhaps most of all his insistence that epidemiologists cannot hide from the wider realities of the world in which they live.

Thus, epidemiologists owe Ian a great debt for his work, and its continuing influence. I want to finish by commenting on two particular aspects of that debt.

First, we are indebted to Ian for doing this work in New Zealand. Too often, leading New Zealand researchers go overseas and the "tall poppy" syndrome means that anyone who stays here is often considered to be "not good enough" to go overseas. Ian has always been a New Zealander and has always been devoted to "making a difference" in this country. In doing so, he, perhaps paradoxically, did scientific work which is of universal interest and is perhaps better recognised overseas than it is here.

Second, we are indebted to Ian for the way that he did this work. It is easy nowadays to look back and to see that Ian has published a few papers and done a few studies, and to imagine that it was not all that difficult. In practice, Ian had huge barriers to overcome to get epidemiology and public health accepted and to do the sort of community-based research that he saw was necessary. As his obituary in the Wellington daily newspaper noted, when Ian Prior first established epidemiology as a field in New Zealand "within senior echelons of the medical fraternity, there were doubts as to whether prodding Māori, checking their blood and measuring fat rolls constituted real research. Even the Medical Research Council at the time would not give Dr Prior ... the stamp of approval. In the end they did, but only after Dr Prior authored a flood of learned papers, and had them published abroad."

Almost everyone who enters public health research, like Ian, has some aspirations to "helping people" and achieving social change. However, most people rapidly get "beaten" and settle down to a nice career with aspirations of a good salary, and a steady accumulation of frequent flyer miles (hence the joke about epidemiology being "the art of turning death rates into frequent flyer miles"). Alternatively, it is easy to be "beaten" in another way, to settle into a "grievance mode" and to spend your career complaining about real or imagined grievances and shortcomings of "the system" without seriously working to overcome these. What both of these approaches have in common is that they (in different ways) benefit (and empower) the individual researchers, but do not benefit public health.

What is much more difficult is, as Ian has done, to move forward in a way that makes sensible compromises and gets things done, but that does not compromise public health principles and keeps public health goals to the forefront. As he frequently used to say "when in doubt, do the courageous thing". "In doing the courageous thing, time after time, Ian tackled the problems of his time, in the context of his time, and overcame them in a way that cleared the path for those who followed. If we can continue this work, in the current context, with a fraction of the spirit and the love (of people and of knowledge) with which Ian approached his work, we will be doing very well indeed.

My favourite story about Ian was when a friend of mine was trying to get a new policy on South Africa established at the Annual General Meeting of the Public Health Association. He was having great problems with colleagues who were older, more senior and more conservative. There were the usual arguments (for the day) about public health researchers "sticking to the science" and not getting involved in politics, even if the politics had a direct effect on health. Ian had just received a special award from the Association, and was having to leave early while the debate was still continuing. As he was leaving, he very publicly thumped my friend (who subsequently won the debate) on the back and said "I've fought these guys all my life. Don't let the bastards beat you".

And he never did.

Acknowledgements: This paper is based in part on two previous papers that I have written on lan Prior's life and work. ${ }^{2}$

Funding: The Centre for Public Health Research is supported by a Programme Grant from the Health Research Council of New Zealand.

Competing interests: None. 


\section{REFERENCES}

1. Pearce N. "When in doubt, do the courageous thing". A celebration of lan Prior's life and work in epidemiology. In: Howden-Chapman P, Woodward A, eds. The health of Pacific societies: Ian Prior's life and work. Wellington: Steele Roberts, 2001:50-60.

2. Pearce N. "Don't let the bastards beat you": Ian Prior and epidemiology in New Zealand. Australas Epidemiologist 2006;13:26-9.

3. Prior IAM, Stanhope JM, Evans JG, et al. Tokelau Island Migrant Study. Int J Epidemiol 1974;3:225-32.

4. Wessen A, Hooper A, Huntsman J, et al, eds. Migration and health in a small society: the case of Tokelau. New York: Oxford University Press, 1992.
5. Pearce N. Traditional epidemiology, modern epidemiology, and public health.[comment]. Am J Publ Health 1996;86:678-83.

6. Pearce N. Epidemiology as a population science. Int $J$ Epidemiol 1999;28:S1015-8.

7. Pearce N. Epidemiology: populations, methods and theories. Eur J Epidemiol 2004;19:729-31.

8. Pearce N, McKinlay JB. Back to the future in epidemiology and public health: response to Dr. Gori. J Clin Epidemiol 1998;51:643-6; discussion 647-9.

9. Kitchin P. A leader in the field of public health. Dominion Post 26 February 2009; 3 .

\section{Important news for readers: all JECH content from 1947 now available online}

We have recently released the full online archive of Journal of Epidemiology and Community Health back to 1947-volume 1, issue 1. All content before 1 January 2006 is FREE online and can be accessed at http://jech.bmj.com/contents-by-date.0.dtl.

\section{Non-subscribers}

If you or your institution does not subscribe to JECH you will have to complete a simple ONE TIME REGISTRATION form to access the content http://journals.bmj.com/cgi/register. Registration will also allow you to take advantage of OTHER FREE SERVICES such as personal folders and custom email alerts. Recent content (after 1 January 2006) is available to subscribers only or on a pay per view basis.

\section{Personal subscribers}

Individuals will sign in to the journal as normal using their username and password. You can take advantage of the 'Remember me' feature on the site or your browser to sign in automatically. If you have forgotten your password or want to update your details visit http://journals.bmj.com/cgi/ changeuserinfo. If you haven't activated your online access you will need to enter your 6 digit customer number here http://journals.bmj.com/cgi/activate/basic.

\section{Institutional customers}

Users covered by an institutional subscription may browse the archive as usual without registration; however, you will need to register to use the personal services. 


\title{
Ian Prior and epidemiology in New Zealand
}

\author{
Pearce, Neil
}

2009-04-26

http://hdl.handle.net/10179/9722

22/04/2023 - Downloaded from MASSEY RESEARCH ONLINE 